\title{
Short-term Creep Properties and Fracture Surface of 18 Ni (300) Maraging Steel Plasma Nitrided
}

\author{
Adriano Gonçalves dos Reis ${ }^{a, b *}$, Danieli Aparecida Pereira Reis ${ }^{c, d}$, Antônio Jorge Abdallad ${ }^{d, e}$, Antônio \\ Augusto Couto $^{b, f}$, Jorge Otubo ${ }^{c, d}$ \\ ${ }^{a}$ Universidade Estadual Paulista (Unesp), Instituto de Ciência e Tecnologia, \\ São José dos Campos, SP, Brazil \\ ${ }^{b}$ Instituto de Pesquisas Energéticas e Nucleares - IPEN, São Paulo, SP, Brazil \\ ${ }^{c}$ Instituto de Ciência e Tecnologia, Universidade Federal de São Paulo - UNIFESP, São José dos \\ Campos, SP, Brazil \\ ${ }^{d}$ Instituto Tecnologico de Aeronautica - ITA, São José dos Campos, SP, Brazil \\ e Instituto de Estudos Avançados - IEAv, São José dos Campos, SP, Brazil \\ ${ }^{f}$ Universidade Presbiteriana Mackenzie - UPM, São Paulo, SP, Brazil
}

Received: September 30, 2016; Revised: February 6, 2017; Accepted: February 18, 2017

\begin{abstract}
Plasma nitriding of a solution annealed and aged 300 grade maraging steel was studied aiming to increase the creep resistance. The surface microhardness reached $1,140 \mathrm{HV}$, producing $50 \mu \mathrm{m}$ layer composed of $\varepsilon-\mathrm{Fe}_{3} \mathrm{~N}$ and $\gamma^{\prime}-\mathrm{Fe}_{4} \mathrm{~N}$ nitrides at the uppermost sample layer. The inner core remained unaltered presenting typical plate-like martensite microstructure of maraging steels with average microhardness of $604 \mathrm{HV}$. Surface RMS roughness in the nanometric scale increase from $52 \mathrm{~nm}$ to $71 \mathrm{~nm}$. The continuous layer of iron nitrides seems to behave as a barrier for oxidation and for inward oxygen diffusion improving the creep resistance by reducing the steady-state creep rate $\left(\varepsilon_{s}\right)$ in $52-65 \%$ when compared with the literature results. Dominant creep mechanism is controlled by dislocations climb. Fracture surfaces of specimens presented ductile failure consisting of equiaxed and bi-modal dimples in the fibrous zone surrounded by $45^{\circ}$ shear lip. Nitrided sample presented a reduced ductility, associated to the hard surface layer.
\end{abstract}

Keywords: maraging, creep, plasma nitriding, fracture

\section{Introduction}

The 18-percent nickel 300 grade maraging steels belong to a family of iron based alloys that are strengthened by a combination of martensite formation during a solution annealing followed by an aging treatment. Since 1959 when their development was announced, maraging steels evoked tremendous interest, especially in the aerospace world, due to the combination of structural strength and fracture toughness in a material that was, at the same time, readily weldable and easy to heat-treat. The large rocket-motor program sparked the considerable research and development of maraging steels, and it is the key application until now. Otherwise, currently maraging steels are applied not only for aerospace, military and nuclear industries, but also for transportation, manufacturing, tooling, die making and electromechanical components. 300 grade maraging steel is a member of ironnickel based alloy family with yield strength of $300 \mathrm{ksi}^{1-4}$.

One of the major factors limiting the life of maraging steels in service is their degradation due to gaseous environments, in particular, to environments containing oxygen at elevated temperatures during long-term use. When maraging steels

* e-mail: adriano.reis@ict.unesp.br are exposed in air, obey a limited oxide layer thickness growth law up to $480{ }^{\circ} \mathrm{C}$ and a parabolic law above this temperature. At $500^{\circ} \mathrm{C}$ and up to $600^{\circ} \mathrm{C}$, the growth rate is faster and increases sharply with increase in temperature. The interaction of maraging steels with oxygen not only causes losses in the material during the formation of oxides but also causes embrittlement in the subsurface zone of the component due to oxygen enrichment, and the creep resistance is often the limiting parameter in design under different temperaturestress domains ${ }^{5-6}$. Therefore, for high temperature service in oxidizing atmospheres, satisfactory creep resistance must be combined with adequate resistance to environmental degradation. Increasing efforts are being directed to the study of superficial thermochemical treatments to improve oxidation and creep resistance of metals and alloys ${ }^{7-10}$. Plasma nitriding is a technique used to introduce elemental nitrogen to the surface of a metal part for subsequent diffusion into the material by ion glow discharge. Plasma nitriding is specially designed for low temperature nitriding, and it is adequate for maraging steels avoiding the overaging ${ }^{11-13}$. Plasma nitriding of maraging steels has been extensively investigated with the aim of improving the alloy's tribological and mechanical properties $^{13-14}$. Otherwise, data available on the mechanical 
properties of maraging steel at elevated temperature under creep are scarce, 15-18. In this study, the creep resistance and fracture surface of a plasma nitrided maraging 300 steel is evaluated and compared with the results obtained by Reis et al. ${ }^{18}$ for the same material but without surface treatment.

\section{Experimental Procedures}

In this study it was used a 300 grade maraging steel with the chemical composition according to Table 1 . The samples were solution treated at $820^{\circ} \mathrm{C}-1 \mathrm{~h}$ and then air cooled followed by aging at $4800^{\circ} \mathrm{C}-3 \mathrm{~h}$ and then air cooled in a Brasimet Koe 40/25/65 furnace, hereafter called MAR-SA. Plasma nitriding was performed using a $30 \mathrm{~kW}$ DC-pulsed source at $480{ }^{\circ} \mathrm{C}$ for $3 \mathrm{~h}$ in an environment atmosphere of $75 \% \mathrm{~N}_{2}-25 \% \mathrm{H}_{2}$, hereafter called MAR-SAP. The microstructural characterization was carried out on Carl Zeiss model Axio Imager 2 optical microscopy - OM. XRD was carried out at room temperature with a $\mathrm{CuK} \alpha$ radiation source on Panalytical model X' Pert Powder diffractometer. Data for each phase were analyzed with X'Pert HighScore using the ICDD database. Hardness was measured using Vickers microhardness Tester (FutureTech model FM-700) with load of $100 \mathrm{~g}$ for $9 \mathrm{~s}$. Surface morphology was analyzed using Nanosurf Flex atomic force microscope - AFM (tapping mode, $\mathrm{SiN}_{3}$ tip model NCHR, Nanoworld). Samples of 18.5 $\mathrm{mm}$ gauge length by $3.0 \mathrm{~mm}$ in diameter were submitted to constant load creep tests at $650^{\circ} \mathrm{C}(200,300$ and $500 \mathrm{MPa})$, $600^{\circ} \mathrm{C}(500 \mathrm{MPa})$ and $550^{\circ} \mathrm{C}(500 \mathrm{MPa})$ in a standard Mayes creep machine, according to ASTM E139 standard ${ }^{19}$. Disks for transmission electron microscopy (TEM) were sliced from the crept samples and pre-thinned by dimple grinder SBT Model 515. Thin foils were then prepared by ion polishing in a GATAN Model 691. Observations of the center of the foils were carried out in a FEI TECNAI model G2F20 TEM. Fractographic analysis were carried out by scanning electron microscopy - SEM (TESCAN model VEGA 3).

\section{Results and Discussion}

\subsection{Microstructural characterization}

Figure 1 is the cross-sectional image of MAR-SAP showing an uniform and continuous hardened nitrided layer of $50 \mu \mathrm{m}$ thick and the typical martensite plate-like microstructure of maraging steels in the un-nitrided core.

The X-ray diffraction (XRD) pattern in the $2 \theta$ ranging from $35-90^{\circ}$ of MAR-SA and MAR-SAP samples are shown in Figure 2. MAR-SA exhibit diffraction peaks only due to the martensitic phase $\alpha^{\prime}-\mathrm{Fe}$, Figure $2 \mathrm{a}$. After plasma nitriding
(MAR-SAP), $\alpha$ '-Fe peaks disappeared or are overlapped, giving place to peaks indexed as $\varepsilon-\mathrm{Fe}_{3} \mathrm{~N}$ (01-076-0091) and $\gamma^{\prime}-\mathrm{Fe}_{4} \mathrm{~N}(00-001-1219)$ nitrides, corresponding to the compound layer, Figure $2 \mathrm{~b}$.

The surface microhardness increased from $604 \pm 18 \mathrm{HV}$ (MAR-SA) ${ }^{18}$ to $1,140 \pm 15 \mathrm{HV}$ (MAR-SAP), after plasma nitriding. The surface microhardness increase of $88.7 \%$ is associated to the formation of $\varepsilon-\mathrm{Fe}_{3} \mathrm{~N}$ and $\gamma^{\prime}-\mathrm{Fe}_{4} \mathrm{~N}$ nitrides, revealed by the XRD result from Figure $2 b$. Figure 3 shows the microhardness profile of MAR-SAP. A comparison of the depth etched out in Figure 1 and the depth-hardness variation in Figure 3 reveals that the etched-out depth $(50 \mu \mathrm{m})$ is the depth of the layer where the nitride phase is predominant, as proved in X-ray diffraction in the Figure 2. Higher values of microhardness are expected in this region. The band from 50 to $100 \mu \mathrm{m}$ is the transition region where the hardness values decrease inward in a different rate, approaching the hardness of the matrix. This is probably the region of solid solution hardening by nitrogen atoms. It should be noted that the core hardness of MAR-SAP remains the same as that of MAR-SA. This confirms that the core does not soften by overaging due to ion nitriding temperature and time.

Plasma nitriding changed the topography on the surface of MAR-SAP sample, according to the three-dimensional AFM images (Figure 4). The layer of iron nitrides being formed led to an increase of surface RMS roughness in the nanometric scale from $52 \mathrm{~nm}$ (MAR-SA), Figure 4a, to $71 \mathrm{~nm}$ (MAR-SAP), Figure $4 \mathrm{~b}$, as measured by AFM microscope. The nitrided surface presented a typical flakelike peaks morphology.

\subsection{Creep behavior}

MAR-SAP samples exhibit typical creep curves consisting of well-defined primary (I), secondary (II) and tertiary (III) stages. Figure 5 displays representative creep curves of strain (E) versus time $(t)$ at $650{ }^{\circ} \mathrm{C}$ and $200 \mathrm{MPa}$. The results from creep tests are summarized in Table 2 , which shows the values of the steady-state creep rate $\left(\varepsilon_{s}\right)$, the time to rupture $\left(t_{r}\right)$ and the percent of elongation $(E L)$. For comparison, the creep data of MAR-SA ${ }^{18}$ is also available in Figure 5 and Table 2 . The $\dot{\varepsilon}_{s}$ values of MAR-SAP are 52-65\% lower and the $t_{r}$ are 20-33\% higher, when compared to MAR-SA. The reduction of $\dot{\varepsilon}$ and increase of $t_{r}$ indicate that a higher creep resistance of MAR-SAP plasma nitrided samples. This fact is related to surface microstructure formed in the plasma nitriding. The continuous layer of $\varepsilon-\mathrm{Fe}_{3} \mathrm{~N}$ and $\gamma^{\prime}-\mathrm{Fe}_{4} \mathrm{~N}$ nitrides behave as a diffusion barrier for inward oxygen diffusion (into the alloy), reducing the oxidation rate and improving the creep resistance of the steel.

Table 1. Chemical composition (wt. \%) of the maraging $300^{18}$.

\begin{tabular}{|c|c|c|c|c|c|c|c|c|c|c|}
\hline $\mathrm{Ti}$ & Co & Mo & $\mathrm{Ni}$ & $\mathrm{Al}$ & $\mathrm{C}$ & $\mathrm{S}$ & $\mathrm{P}$ & $\mathrm{Si}$ & $\mathrm{Mn}$ & $\mathrm{Fe}$ \\
\hline 0.63 & 9.37 & 4.94 & 19.00 & 0.08 & 0.008 & 0.002 & 0.004 & 0.06 & 0.01 & Balance \\
\hline
\end{tabular}




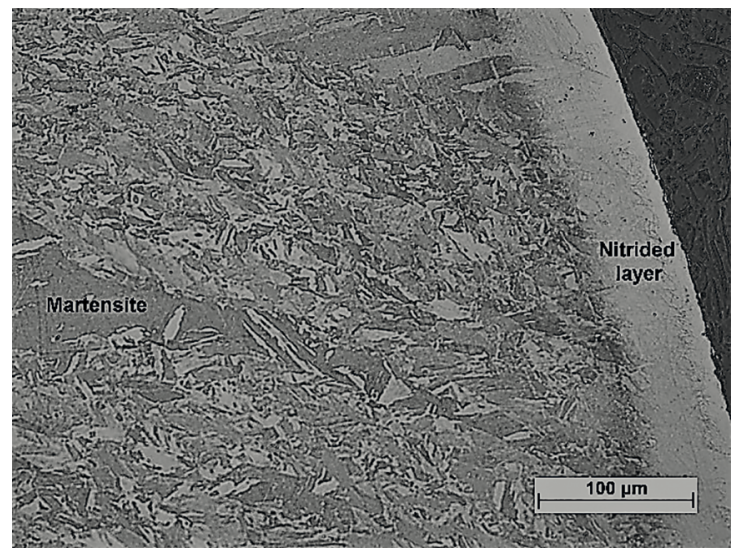

Figure 1: Optical micrograph of the MAR-SAP showing the nitrided layer and typical plate-like martensite microstructure of maraging steels in the un-nitrided core.

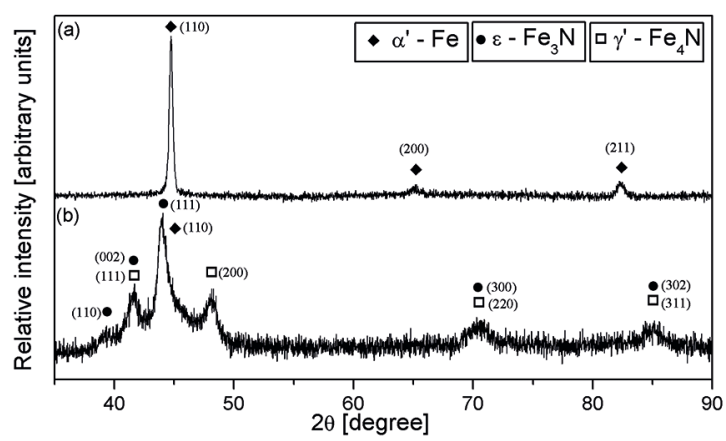

Figure 2: X-ray diffraction pattern of (a) MAR-SA and (b) MAR-SAP.

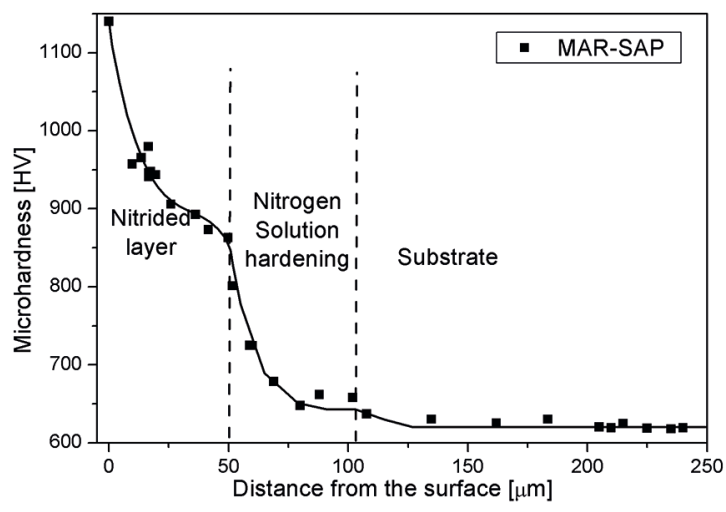

Figure 3: Microhardness profile of MAR-SAP.

The creep results of maraging 300 steel (nitrided an unnitrided) at the temperature range of $550{ }^{\circ} \mathrm{C}$ to $650{ }^{\circ} \mathrm{C}$ is also affected by martensite reversion to austenite, that deteriorates mechanical properties. The literature reports an $\mathrm{A}_{\mathrm{s}}$ (Austenite formation start) of $623{ }^{\circ} \mathrm{C}$ and $\mathrm{A}_{\mathrm{f}}$ (Austenite formation finish) of $801{ }^{\circ} \mathrm{C}$, but exposure at temperatures even below $\mathrm{A}_{\mathrm{s}}$ can produces different amount of reverted austenite. The reason is that the martensite that is formed during solution

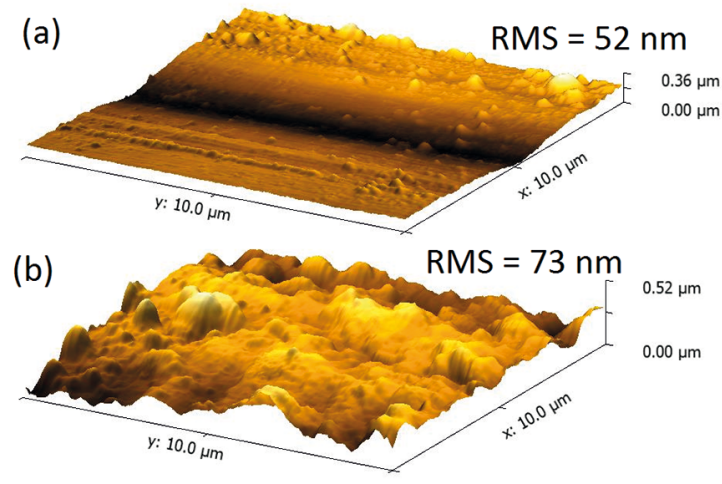

Figure 4: Three-dimensional AFM images $(10.0 \mu \mathrm{m} \times 10.0 \mu \mathrm{m})$ of surface topography of (a) MAR-SA and (b) MAR-SAP.



Figure 5: Creep curves of MAR-SA ${ }^{18}$ and MAR-SAP at $650{ }^{\circ} \mathrm{C}$ and $200 \mathrm{MPa}$.

Table 2: Creep data of MAR-SA ${ }^{18}$ and MAR-SAP at $650{ }^{\circ} \mathrm{C}$.

\begin{tabular}{lcccc}
\hline Treatment & $\begin{array}{c}\sigma \\
{[\mathrm{MPa}]}\end{array}$ & $\begin{array}{c}(\dot{\mathrm{s}}) \\
{[1 / \mathrm{s}]}\end{array}$ & $\begin{array}{c}t_{r} \\
{[\mathrm{~s}]}\end{array}$ & $\begin{array}{c}\text { EL } \\
{[\%]}\end{array}$ \\
\hline \multirow{3}{*}{ MAR-SA $^{18}$} & 200 & $5.75 \times 10^{-6}$ & 105,660 & 28.4 \\
& 300 & $7.97 \times 10^{-6}$ & 7,200 & 36.7 \\
& 500 & $3.72 \times 10^{-4}$ & 181 & 25.0 \\
& 200 & $2.63 \times 10^{-7}$ & 132,948 & 21.7 \\
MAR-SAP & 300 & $3.83 \times 10^{-6}$ & 8,640 & 22.1 \\
& 500 & $1.31 \times 10^{-4}$ & 240 & 20.8 \\
\hline
\end{tabular}

treatment is metastable and the system decomposes to the equilibrium austenite and ferrite structures via diffusioncontrolled reactions ${ }^{18,20-22}$. Specialized applications of the steel occasionally demand short-time exposures to high temperatures and it is desirable to have data on the creep behavior of the material during such service conditions.

For most metal and alloys, the relationship between the steady-state creep rate $\left(\dot{\varepsilon}_{\mathrm{s}}\right)$, stress $(\sigma)$ and temperature $(T)$ can be expressed by the power-law creep equation:

$$
\dot{\varepsilon}_{S}=A \sigma^{n} \exp \left(-Q_{C} / R T\right)
$$


where $Q_{c}$ is the activation energy for creep, $A$ is a constant that depends on the microstructure, temperature and applied stress $(\sigma), n$ is the stress exponent, $R$ is the universal gas constant and $T$ absolute temperature. The combination of $Q_{c}$ and $n$ values indicates the main creep mechanism that controls a given deformation process ${ }^{23}$. The slopes of the plot $\ln \varepsilon_{s}^{*} x \ln \sigma$, which is presented in Figure 6, provide an estimate of $n$. The dependence of the steady-state creep rate on temperature at $500 \mathrm{MPa}$ is presented in Figure 7 and Table 3. The values of $n=7.1 / Q_{c}=428 \mathrm{~kJ} / \mathrm{mol}$ (MAR-SA) ${ }^{18}$ and $n$ $=6.8 / Q_{c}=388 \mathrm{~kJ} / \mathrm{mol}$ (MAR-SAP) are in accordance with results reported in the literature to materials hardened by a dispersion of a second-phase particles that are considerably higher than the values expected for the appropriate base materials (iron: $n=5$ and $Q_{c}=284 \mathrm{~kJ} / \mathrm{mol}$ ). The expected stress exponent values for these materials are in the range of 5 to $15^{23,24}$. Furthermore, Viswanathan et al. ${ }^{15}$ who used indentation technique for evaluating high temperature creep of 350 grade maraging steel, obtained $Q_{c}$ values between $405 \mathrm{~kJ} / \mathrm{mol}$ and $467 \mathrm{~kJ} / \mathrm{mol}$.

The analysis of the values of the activation energy and stress exponent suggests that the creep mechanism is associated with dislocation climbing process ${ }^{23,24}$. Figure 8 shows TEM image of the crept samples at $6500^{\circ} \mathrm{C}$ and 500 $M P a$. The micrograph depicts dislocation cell structures.



Figure 6: Dependence of steady-state rate on applied stress at 650 ${ }^{\circ} \mathrm{C}$ for MAR-SA ${ }^{18}$ and MAR-SAP (the slope is $n$ ).

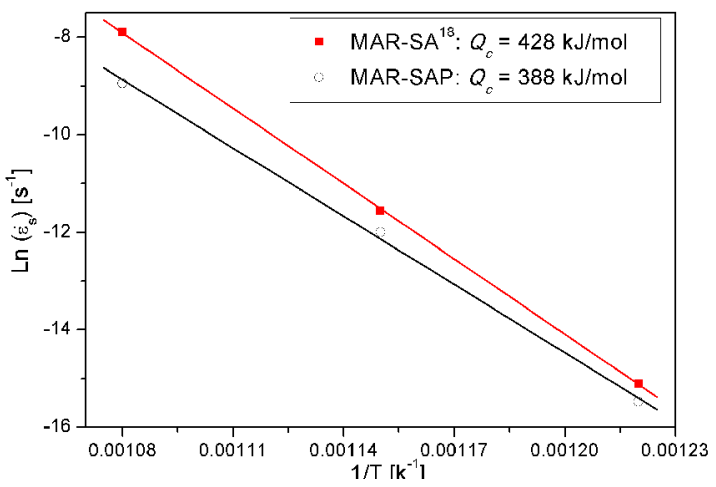

Figure 7: Dependence of steady-state rate on temperature at 500 MPa for MAR-SA ${ }^{18}$ and MAR-SAP (the slope is $-Q_{c} / R$ ).
Table 3: Steady-state creep rate $(\dot{\varepsilon})$ of MAR-SA ${ }^{18}$ and MAR-SAP at $500 \mathrm{MPa}$.

\begin{tabular}{lcc}
\hline \multirow{2}{*}{ Temperature $\left[{ }^{\circ} \mathrm{C}\right]$} & \multicolumn{2}{c}{ Steady-state creep rate $\left(\dot{\varepsilon_{s}}\right)[1 / \mathrm{s}]$} \\
& MAR-SA $^{18}$ & MAR-SAP \\
\hline 550 & $2.77 \times 10^{-7}$ & $1.91 \times 10^{-7}$ \\
600 & $9.56 \times 10^{-6}$ & $6.14 \times 10^{-6}$ \\
650 & $3.72 \times 10^{-4}$ & $1.31 \times 10^{-4}$ \\
\hline
\end{tabular}

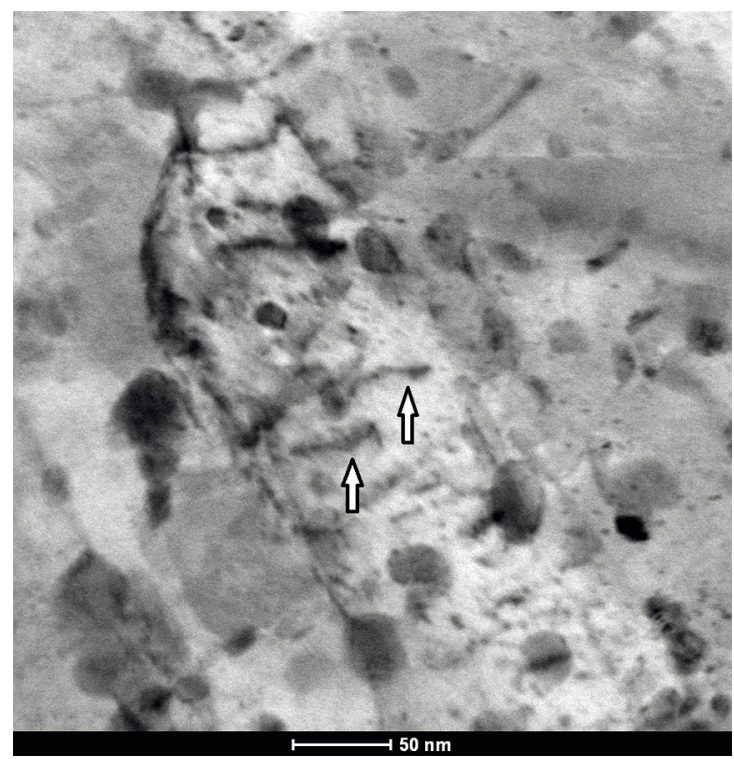

Figure 8: TEM bright field micrograph of MAR-SAP crept at 650 ${ }^{\circ} \mathrm{C}$ and $500 \mathrm{MPa}$ showing dislocations.

\subsection{Characteristics of fracture surfaces}

Both the MAR-SA ${ }^{18}$ and the MAR-SAP samples showed a cup-and-cone fracture morphology after creep tests, characteristic of a ductile type of failure. Figure 9a is a representative SEM micrograph showing the general view of the fracture surface of the MAR-SA sample crept at 650 ${ }^{\circ} \mathrm{C}$ and $300 \mathrm{MPa}$, consisting of dimpled rupture surrounded by shear lips. Figure $9 b$ is a higher magnification image of the equiaxed dimples at the location enclosed in Figure 9a.

Otherwise, from Table 2 it can be noticed that the ductility (elongation, \%) decreased after plasma nitriding, considering all stress conditions of creep tests. The ductility of the MAR-SAP are 17 to $40 \%$ lower than that of MARSA samples. Ductility reduction of nitrided sample is also observed by fractographic analysis.

The fracture surface of MAR-SAP crept at $650{ }^{\circ} \mathrm{C}$ and $300 \mathrm{MPa}$ is illustrated in Figure 10a, showing a dimpled rupture region at the center surrounded by shear lips and encircled by a narrow rim. Equiaxed dimples were observed in the dimpled region in the center part of fracture surface, (Figure 10b). Higher magnification observation revealed that the narrow rims presented a flat fracture with cleavage facets, (Figure 10c). The average width of the narrow rim is 100 $\mu \mathrm{m}$, and it is close to the value found in the microhardness 

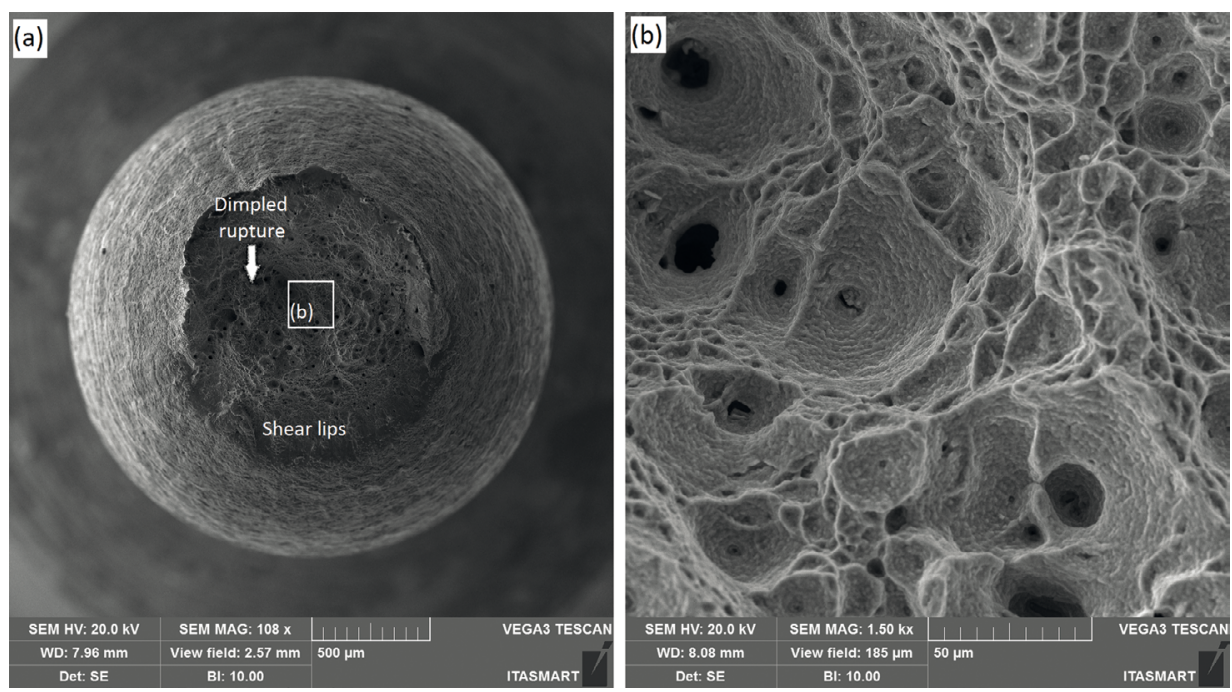

Figure 9: Secondary electron SEM images showing the fracture morphology of the MAR-SA crept at $650{ }^{\circ} \mathrm{C}$ and $300 \mathrm{MPa}$. (a) The dimpled rupture surrounded by shear lips (characteristic of ductile fracture). (b) Equiaxed dimples at the location enclosed in Fig. 9a.
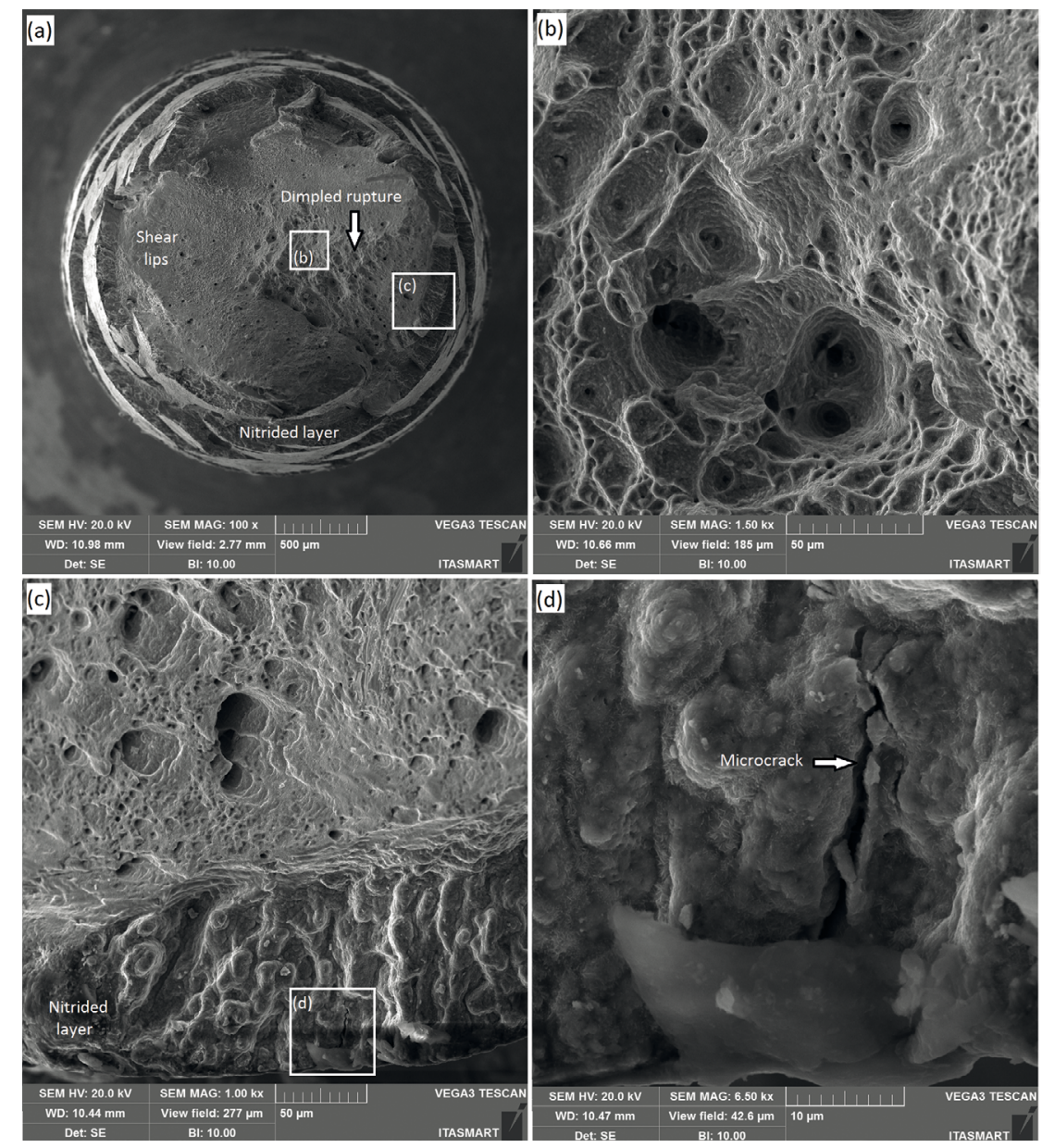

Figure 10: Secondary electron SEM images showing the fracture surface of the MAR-SAP crept at $650{ }^{\circ} \mathrm{C}$ and $300 \mathrm{MPa}$. (a) General morphology showing a cup and cone type of failure, the enclosed areas are the location where higher magnification in Figs. $9 \mathrm{~b}$ and $9 \mathrm{c}$ were taken. (b) Dimpled rupture area observed in the enclosed area marked as "b" in Fig. 9a. (c) A brittle type of fracture in the surface vicinity (nitrided layer), the enclosed area is where a higher magnification image in Fig. 9d was taken. (d) Cleavage surface and formation of microcracks close to the surface. 




Figure 11: Secondary electron SEM image showing the circumferential cracks on the surface of plasma nitrided alloy crept at $650{ }^{\circ} \mathrm{C}$ and $300 \mathrm{MPa}$ with cracks perpendicular and cross-linked at a $45^{\circ}$ angle relative to the tensile loading direction.

profile (Figure 3). It can be associated to the iron nitrides formed and nitrogen solution hardening regions after plasma nitriding. Microcracks initiating from the surface were observed near the surface as shown in Figure 10d. The higher ductility of MAR-SA compared to MAR-SAP could also be inferred from top view of Fig 9a and 10a respectively. The fibrous fracture area of MAR-SA is $35 \%$ smaller than that of MAR-SAP indicating higher ductility for the first.

Figure 11 is a side view SEM image of MAR-SAP sample after rupture showing the formation of circumferential (transverse) microcracks on the nitrided surface perpendicular and cross-linked at $45^{\circ}$ angle relative to the tensile loading direction.

Creep fracture has been described by the phenomenological Monkman-Grant relationship ${ }^{25}$, which states that the fracture of creep-deforming material is controlled by the steady-state creep rate according Equation 2:

$$
t_{r}\left(\dot{\varepsilon}_{S}\right)^{M}=C
$$

Where $M$ is a constant typically about 1.0 (when following the Monkman-Grant relationship) and $C$ is referred to as Monkman-Grant constant. However the value of $C$ is material dependent, the values normally observed is in the range of 0.001 to 0.1 . As a general rule, larger $C$ values tend to be recorded for materials displaying higher creep ductility ${ }^{23}$. Figure 12 shows the Monkman-Grant correlation of MAR-SA and MAR-SAP. For both cases, $M$ is around 1.0 (MAR-SA $=1.017$ and MAR-SAP ${ }_{M}=0.968$ ), independent of creep testing temperature and stress regime. This indicates that the creep rupture of the 300 grade maraging steel nitrided and un-nitrided follow the Monkman-Grant relationship for



Figure 12: Correlation between steady-state creep rate $(\dot{\varepsilon})$ and time to fracture $\left(\mathrm{t}_{\mathrm{r}}\right)$ for MAR-SA ${ }^{18}$ and MAR-SAP from 550 to $650{ }^{\circ} \mathrm{C}$.

the stress and temperature studied. Monkman-Grant constant $\mathrm{C}$ is smaller in the MAR-SAP $(\mathrm{C}=0.0270)$ compared with MAR-SA ${ }^{18}(\mathrm{C}=0.0683)$, which result from the reduction of creep ductility after plasma nitriding.

Therefore, ductility measurement, fractography and Monkman-Grant relationship show a reduction of ductility and cracks propagation in the surface in the MAR-SAP when compared to MAR-SA ${ }^{18}$. During the plasma nitriding, nitrogen atoms are diffused into the surface and near-surface regions. Because the atoms occupy space in the lattice, they tend to produce compressive residual stress parallel to the surface that can be used to neutralize, or counteract, potentially damage tensile applied stress ${ }^{26}$. Therefore, the compressive residual stress on the nitrided layer of MAR-SAP sample act as a barrier to the elongation reducing the ductility when compared to un-nitrided samples. Once the tensile stress during the creep test overcomes the compressive residual stress, the cracks in the surface start to propagate, and the plastic deformation will concentrate in this region. The higher RMS roughness showed in Figure 4 by MAR-SAP sample indicates the higher roughness of the nitrided layer and may contribute to the presence of stress concentrators on the layer's surface to initiate the crack. Although this characteristic is negative to the creep resistance, the positive effect of oxidation barrier from the nitrided layer compensates the ductility loss, and the overall creep resistance is improved at the end.

\section{Conclusions}

The following concluding remarks could be drawn based on plasma nitrided and un-nitrided 300 grade maraging steel:

- An uniform $50 \mu \mathrm{m}$ thick surface layer of $\varepsilon-\mathrm{Fe}_{3} \mathrm{~N}$ and $\gamma \cdot-\mathrm{Fe}_{4} \mathrm{~N}$ was formed, increasing the surface microhardness from $604 \pm 18 \mathrm{HV}$ to $1,140 \pm 15 \mathrm{HV}$ and RMS roughness in the nanometric scale from $52 \mathrm{~nm}$ to $71 \mathrm{~nm}$, respectively for un-nitreded an nitrided regions. The continuous hardness decrease from surface to the core of the sample suggests the 
presence of two regions: one where the nitride phases are predominant and other with solution hardening by nitrogen atoms. The un-nitrided core remained un-altered, showing the typical hardness value and plate-like martensite microstructure;

- Typical creep curves consisting of well-defined primary, secondary and tertiary stages were found. Creep resistance of nitrided samples improved from $52-65 \%$ when compared to un-nitrided samples, and it seems to be associated with the continuous layer of iron nitrides that behave as a diffusion barrier for inward oxygen diffusion into the alloy reducing the oxidation rate.

- $\quad$ Based on the stress exponent ( $n$ ), activation energy for creep $\left(Q_{c}\right)$ and heterogeneous dislocation structure, it is concluded that the dominant creep mechanism is primarily controlled by dislocation climb.

- Dominant type of failure was ductile showing a typical cup-and-cone fracture morphology, consisting of equiaxed and bi-modal dimples in the fibrous zone surrounded by $45^{\circ}$ shear lip. The ductility of the nitrided samples are $17-40 \%$ lower, confirmed by Monkman-Grant relationship and fractographic analysis, and it is associated to the hard surface layer.

\section{Acknowledgements}

The authors are grateful to $\mathrm{CNPq}$ [grant numbers 141274/2013-1 and 403070/2016-3], CAPES [grant number Projec Pro-Defesa 014/08], LCS/LNNano/CNPEM (AFM), FAPESP and FINEP-PROINFRA. Thank is also to Prof. Carlos de Moura Neto (in memoriam).

\section{References}

1. Pereloma E, Edmonds DV, eds. Phase transformations in steels: Diffusionless transformations, high strength steels, modelling and advanced analytical techniques. $1^{\text {st }}$ ed. Cambridge: Woodhead Publishing Limited; 2012.

2. Sha W, Guo Z. Maraging Steels: Modelling of Microstructure, Properties and Applications. Boca Raton: Woodhead Publishing Limited; 2009.

3. Hall AM, Slunder CJ. The metallurgy, behavior, and application of the 18-percent Nickel Maraging steels: A survey. Washington: Technology Utilization Division, National Aeronautics and Space Administration; 1968.

4. Schmidt M, Rohrbach K. Heat treating of Maraging Steels. In: ASM Handbook Committee. ASM Handbook: Heat treating. Volume 4. Materials Park: ASM International: 1991. p. 528-548.

5. Greyling CJ, Kotzé IA, Viljoen PE. The kinetics of oxide film growth on maraging steel as described by space-charge effects. Surface and Interface Analysis. 1990;16(1-12):293-298.

6. Abe F, Kern TU, Viswanathan R. Creep-resistant steels. $1^{\text {ts }}$ ed. Cambridge: Woodhead Publishing; 2008.
7. Oliveira AC, Oliveira RM, Reis DAP, Carreri FC. Effect of nitrogen high temperature plasma based ion implantation on the creep behavior of Ti-6Al-4V alloy. Applied Surface Science. 2014;311:239-244.

8. Reis AG, Reis DAP, Moura Neto C, Barboza MJR, Oñoro J. Creep behavior and surface characterization of a laser surface nitrided Ti-6Al-4V alloy. Materials Science and Engineering A. 2013;577:48-53.

9. Swindeman RW, Douglas DA. Improvement of the high-temperature strength properties of reactor materials after fabrication. Journal of Nuclear Materials. 1959;1(1):49-57.

10. Issartel C, Buscail H, Caudron E, Cueff R, Riffard F, Perrier S, et al. Influence of nitridation on the oxidation of a 304 steel at $800^{\circ} \mathrm{C}$. Corrosion Science. 2004;46(9):2191-2201.

11. Reis AG, Reis DAP, Abdalla AJ, Otubo J, Zepka S, Couto AA, et al. Effect of Simultaneous Plasma Nitriding and Aging Treatment on the Microstructure and Hardness of Maraging 300 Steel. In: Öchsner A, Altenbach H, eds. Advanced Structured Materials. Volume 70 - Mechanical and Materials Engineering of Modern Structure and Component Design. New York: Springer International Publishing; 2015. p. 277-284.

12. Yan MF, Wu YQ, Liu RL. Plasticity and ab initio characterizations on $\mathrm{Fe}_{4} \mathrm{~N}$ produced on the surface of nanocrystallized $18 \mathrm{Ni}$ maraging steel plasma nitrided at lower temperature. Applied Surface Science. 2009;255(21):8902-8906.

13. Fernándes de Ara J, Almandoz E, Palacio JF, Fuentes GG, Rodríguez RJ, García JA. Influence of temperature in arc-activated plasma nitriding of maraging steel in solution annealed and aged conditions. Surface and Coatings Technology. 2014;258:754-762.

14. Shetty K, Kumar S, Raghothama Rao P. Effect of ion nitriding on the microstructure and properties of maraging steel (250 Grade). Surface and Coatings Technology. 2009;203(10-11):1530-1536.

15. Viswanathan UK, Kutty TRG, Keswani R, Ganguly C. Evaluation of hot hardness and creep of a 350 grade commercial maraging steel. Journal of Materials Science. 1996;31(10):2705-2709.

16. Gurewitz G, Atzmon N, Rosen A. Creep and stress relaxation in 18\% Ni (250) maraging steel. Metals Technology. 1977;4(1):62-65.

17. Campbell JE, Barone FJ, Moon DP. The mechanical properties of the 18 per cent nickel maraging steels. Columbus: Defense Metals Information Center - Battelle Memorial Institute; 1964.

18. Reis AG, Reis DAP, Abdalla AJ, Otubo J. High-temperature creep resistance and effects on the austenite reversion and precipitation of $18 \mathrm{Ni}$ (300) maraging steel. Materials Characterization. 2015;107:350-357.

19. American Society for Testing and Materials (ASTM). ASTM E139-11. Standard Test Methods for Conducting Creep, CreepRupture, and Stress-Rupture Tests of Metallic Materials. West Conshohocken: ASTM International; 2011. 14 p.

20. Carvalho LG, Andrade MS, Plaut RL, Souza FM, Padilha AF. A Dilatometric study of the phase transformations in 300 and 350 maraging steels during continuous heating rates. Materials Research. 2013;16(4):740-744.

21. Reis AG, Reis DAP, Abdalla AJ, Otubo J, Sandim HRZA. A dilatometric study of the continuous heating transformations in maraging 300 steel. IOP Conference Series: Materials Science and Engineering. 2015;97(1):012006. 
22. Reis AG, Reis DAP, Abdalla AJ, Couto AA, Otubo J. An In Situ High-Temperature X-Ray Diffraction Study of Phase Transformations in Maraging 300 Steel. Defect and Diffusion Forum. 2017;371:73-77.

23. Evans RW, Wilshire B. Introduction to creep. London: The Institute of Materials; 1993.
24. Bressers J. Creep and Fatigue in High Temperature alloys. London: Applied Science Publishers; 1981.

25. Monkman FC, Grant NJ. An empirical relationship between rupture life and minimum creep rate in creep-rupture tests. ASTM Proceeding. 1956;56:593-620.

26. Wulpi DJ, Miller B. Understanding How Components Fail. $3^{\text {rd }}$ ed. Materials Park: ASM International; 2013. 350 p. 